\title{
"An Oriental Orientalist": Aḥmad Zakī Pasha (1868-1934), Egyptian Statesman and Philologist in the Colonial Age
}

\author{
Umar Ryad \\ University of Leuven \\ amr.ryad@kuleuven.be \\ In Memorian Prof. Dr. Gino Schallenbergh (1965-2017)
}

\begin{abstract}
The article sheds light on an important episode of the Arab-Orientalist encounter in the late nineteenth and early twentieth century by highlighting the role of the Egyptian scholar Ahmad Zakī Pasha (1868-1934) in Orientalist circles, his travels to Europe, and his contributions to Arabic linguistic and cultural revival as well as politics. The study looks at his contribution as a member of the international scholarly circles of Arabic and Islamic studies. It will be shown that his engagement with European Orientalists was inseparable from his endeavors to 'revive' the Arabic heritage (ihyā' al-turāth), an engagement that was rooted in his discourse of 'Arabism' (al-'urūba).
\end{abstract}

\section{Keywords}

Ahmad Zakī Pasha - Egypt - Orientalism - Europe - Colonialism - Arabic - Printing Translation - Travel

* This is the description of the Syrian historian Muhammad Kurd 'Alī (1876-1953). See Anwar alJundī, Ahmad Zakī al-Mulaqqab bi Shaykh al-'Urūba, Cairo: Ministry of Culture and National Guidance, 1963, 121.

** I am grateful to the European Research Council under the European Union's seventh frame-

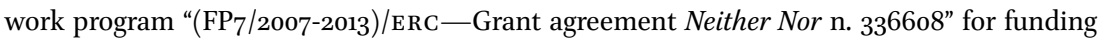
the project Muslims in Interwar Europe at Utrecht University (2014-2017) and the University of Leuven (2017-2019). I would like also to thank the two anonymous reviewers for their constructive suggestions to improve the manuscript. My gratitude is also due to my friends Dr. John Slight and Dr. Islam Dayeh for their valuable comments and edits of the article. 


\section{Introduction}

Orientalism is commonly viewed as the manufacture of knowledge which "occidental" scholars used to represent the Orient to several ends. In various areas such as politics, diplomacy, and colonial power, the exotic nature as well as knowledge production about the Orient had shaped the nature of Orientalism in the modern age. Nevertheless, it is a mistake to claim that Orientalism in the colonial period was a solely European exercise in which "Orientals" had no place. In the case of the Arab encounter with Orientalists in the pre-modern and modern times, in particular, we come across Muslim and Christian Arab scholars who had contacts and cooperated with Western scholars in producing that knowledge. ${ }^{1}$

In his comprehensive study of the contacts between Arab intellectuals and Orientalists, Ronen Raz evaluated "the intellectual and psychological processes which were involved in these relations" in the nineteenth and first half of the twentieth century. ${ }^{2}$ In order to understand the mechanisms and meanings of the relations between Arab intellectuals and Orientalists, his study analyzes "an intellectual discourse" in the broader sense, ${ }^{3}$ beyond individual case studies. The study of individual case studies is nevertheless necessary, in order to understand the multi-layered nature of individuals' encounters in the global history of knowledge production. ${ }^{4}$

Most contacts between Orientalists and Arab scholars took place in the colonies or in Europe. Those who did not have any direct relations with Orientalists had access to their knowledge through translations and reviews and responses in the Arab press. ${ }^{5}$ A group of Arab elite intellectuals developed a "counter-genre" of literature in which they tried to explain Orientalism and the West to Arab readers. Compared to the relatively large number of European Orientalists, travelers, painters and journalists who left behind several accounts

1 See, for example, John Arberry, "A Fresh Light on Ahmad Faris al-Shidiaq," Islamic Culture, 26/1 (Jan. 1952), 155-168; Jason Thompson, "Edward William Lane's 'Description of Egypt", IJMES, 8 iv (Nov. 1996), 565-583; Donald P. Little, ed., Essays on Islamic Civilization (Leiden: Brill, 1976). For a detailed list of 19th century Arab accounts on Europe, see, Daniel Newman, "Myths and realities in Muslim Alterist discourse: Arab travellers in Europe in the age of the Nahda (19th c.)," Chronos, 6 (2002), 7-76.

2 Ronen Raz, "The transparent mirror: Arab intellectuals and orientalism, 1798-1950," Unpublished PhD Thesis, Princeton University, 1997, 24.

3 Raz, "The transparent mirror," 31.

4 Raz, "The transparent mirror," 41.

5 See, for example, J. Heyworth-Dunne, "Printing and Translation under Muhammad Ali of Egypt," Journal of the Royal Asiatic Society, 2/3 (June 1940), 325-349. 
of the Arab world in different European languages, the number of Arab travelers and intellectuals who left similar accounts about the West is not very large. It is noteworthy that the regular International Congress of Orientalists became a significant avenue where non-Europeans met directly with their Orientalist interlocutors. The first International Congress of Orientalists was convened in Paris in 1873. Although some Ottoman, Persian and Indian intellectuals participated in early Orientalist congresses, it was not until the sixth session of the Congress (Leiden, 1883) that Arab intellectuals took active part in it. ${ }^{6}$

This article analyses an important episode of the Arab-Orientalist encounter in the late nineteenth and early twentieth century by highlighting the role of the Egyptian scholar Ahmad Zakī Pasha (1868-1934) in Orientalist circles, his travels to the Europe, and his contributions to the discourse of Arabic linguistic and cultural revival. With a similar status as that of the Egyptian modernist Rifā́a al-Ṭahțāwī (1801-1873), Zakī Pasha was "the only Muslim traveller to be recognized as a full, rather than token member of the international scholarly community, as witnessed by, for instance, his contributions to European publications, and invitations by European scientific academies." ${ }^{7}$

Zakī Pasha's multifaceted scholarly endeavors fit well into Dietrich Jung's argument that "like European intellectuals, non-Europeans developed their own semantics to grasp and debate the modern condition related to different historical trajectories, popular narratives and religious traditions." ${ }^{8}$ In that sense, Zakī Pasha played different intellectual and political roles. To mention just a few, he occupied an important official post as the Secretary-General of the Egyptian Cabinet and became a member of several learned institutions such as the Institut d'Égypte, the Royal Geographical Society and the Royal Asiatic Society in London. These posts gave him the title "Dean of Arabism" (Sheikh al-Urüba). He also represented the Egyptian government at several European International Congresses of Orientalists and archaeology, especially the congresses of Orientalists in London (1892), Geneva (1894), Hamburg (1902) and Athens (1912); and the Exposition Universelle in Paris (1900).

As a member of this scholarly world, Zakī Pasha should be seen as part of the process of the "invention of the Muslim world", which Cemil Aydin has recently

6 Raz, "The transparent mirror," 57-58; see also Transactions of the Second Session of the International Congress of Orientalists, edited by Robert K. Douglas, London: Trübner \& Co., 1876; Travaux de la troisieme session du congres international des orientalistes. 2 nd vol. (St. Petersburg: 1879-188o; Het Leidsche Orientalistencongres, Leiden: Brill, 1883, 24-54.

7 Newman, "Myths and realities," 26.

8 Dietrich Jung Orientalists, Islamists and the Global Public Sphere: A Genealogy of the Modern Essentialist Image of Islam, Equinox Publishing, 2011, 115. 
suggested. Aydin argues that late nineteenth-century Muslim intellectuals attempted to articulate a concept of Islamic civilization in order to make Islam compatible with modernity. ${ }^{9}$ Through their encounters with European ideas and European colonialism, Muslim reformers contested European claims of Muslim inferiority by trying to "redefine the history, civilization, and achievements of Muslim peoples, producing a rich body of ideas and global discourses in which Europeans engaged." ${ }^{10}$ As this article will demonstrate, Zakī Pasha's direct encounters with Orientalists were paralleled by his endeavors of transmission and rigorous study of the Arabic heritage (turäth), which were entrenched in his adoption of the concept of 'Arabism.' It is obvious that the use of Orientalism here does not denote any reference to the concept in the Saidian sense. Although Zakī Pasha's name is connected to Arabism and Orientalism, his celebrated roles culminated in the field of Arabicization of non-Arabic vocabularies and revival of Arab literature and culture.

\section{Aḥmad Zakī Pasha and His Generation}

In his rich biography, the Egyptian writer Anwar al-Jundī (1917-2002) traced Zakī Pasha's multifaceted life and legacy as part of al-Jundīs biographical series of A'täm al-'Arab (Arab luminaries). The work primarily aims to highlight Zakī Pasha among those whom al-Jundī considered as Arab "geniuses" that should be "presented to the contemporary generation that has a thirst for the images of [Arab] heroism in all fields; and for masterpieces of [Arab] intellect and literary arts." ${ }^{\prime 1}$ It took al-Jundī seven years to finish the biography by using many of Zakī Pasha's contributions to the Egyptian press. It is sometimes difficult to trace al-Jundi's sources, as he did not systematically quote them. The present article focuses on Zakī Pasha as bureaucrat, mediator and intellectual celebrity by making use of Jundī's work, source material drawn from Zakī Pasha's personal papers at the National Archives of Egypt, as well as his published material and articles in the Egyptian press. ${ }^{12}$

9 Cemil Aydin, The Idea of the Muslim World: A Global Intellectual History, Cambridge, Massachusetts: Harvard University Press, 2017.

$10 \quad$ Aydin, The Idea, 69 .

11 Jundī, Ahmad Zakī, 3.

12 I would like to thank Dr. Neven Mūsā, director of the National Archives of Egypt, for helping locate Zakī Pasha's private papers in the collections of the archive. I am very grateful to my friend Muhammad Ḥarbī, a journalist at Al-Ahrām, for sending me copies of many of Zakī Pasha's articles in Al-Ahrām. 
Zaki Pasha was born in Egypt to a Moroccan father and an Egyptian mother. As a merchant, his father first worked in Palestine, and later settled in Alexandria. Due to an unsuccessful career in commerce, his father joined the Egyptian army and fought against the British invasion of Alexandria in 1882. It is said that in a military confrontation he fired at an English battleship. ${ }^{13}$ Zakī Pasha's discovery of Europe and his passion for travelling began in his childhood. As a young boy, he regularly accompanied his father to watch European traders sailing on their ships on the Nile to sell furniture and home accessories to the dwellers of the Nile Valley. It fascinated him to see these ifranj (Frankish) vendors, their dress and body features. ${ }^{14}$

Ahmad Zakìs father died when he was a young boy. His older brother Mahmūd Rashād (1854-1925), a judge and head of the National Tribunal in Cairo, took custody of Ahmad Zaki. Ahmad Zakī remained indebted to his brother and his private library which was one of his biggest sources of inspiration in Zaki's youth. In his brother's house he became acquainted with major Arabic and French literary works. It is important to note that Mahmūd Rashād himself attended the Congress of Orientalists in Vienna in 1886 with other Egyptian officials and was one of the early Arab travelers to Russia in modern times. ${ }^{15}$ Rashād's role in Zakì's life was significant to the degree that he usually addressed him as: "my fatherly brother." In his youth, Zakī was brought up under his brother's strict discipline. Rashād's literary circle of friends and their regular gatherings in his house in Cairo also left a great imprint on Zaki's interests in literature, Arabic grammar, poetry and geography. ${ }^{16}$

As a teenager, Ahmad Zakī attended the Khidīwiyya Military Boarding Secondary School in Cairo (founded in 1836), which had very strict rules of punishment by "detention," "eating dry bread" and sometimes "lashing." At this school, he excelled in Arabic grammar and syntax, but often rebelled against school discipline which sometimes led to the punishment of detention. As

\footnotetext{
13 Interview with Aḥmad Zakī Pasha, Al-Hilāl, vol. 35/5, 1 March 1927, 523.

14 Aḥmad Zakī, al-Safar ilā al-Mu’tamar, Cairo: Bulāq, Second Edition, 1894, 7-8.

15 Rashad Bik, Siyāha fì al-Rüsiyya, Hindawi Foundation for Education and Culture, 2012; available at http://www.hindawi.org/books/40206035/ (accessed 20 October 2017). Rashād resigned from his judicial post after he had pronounced a verdict of acquittal to the Egyptian nationalist 'Abd al-Azīz Jāwish and the British Agency and the Palace tried to compel him to change the verdict. After his resignation, he toured around Russia and Europe and wrote many press articles in Al-Mu'ayyad and Al-Ahrām about these travels. See al-Jundī, A A hmad Zakī, 27-28.

16 Al-Jundī, Aḥmad Zakī, 32.
} 
a schoolboy, he was most inclined to amusement, mockery, and April Fool's jokes. ${ }^{17}$

After graduating from secondary school, Zakī studied Law in Cairo. Among his fellows at this school, we find the Moroccan-Egyptian 'Umar Luṭî (18671911), an economic reformer, and the well-known Egyptian nationalist and later exile in Europe Muhammad Farīd (1868-1919). ${ }^{18}$ After his graduation in Law (1887), Zakī worked in the same year as a translator in Suez; in 1889, he moved his translation career to the Council of Ministers. The Azharite Sheikh Muhammad al-Basyūnī al-Bībānī (d. 1892 $)^{19}$ recommended Zakī to this job by informing the Khedive of Egypt about Zakì's mastery of translation. ${ }^{20}$ In his early career, Ahmad Zakī also worked as an editor for the Egyptian newspaper al-Waqä'ic al-Mișriyya (established in 1828) where he came close to the ideas of Egyptian scholars and politicians, such as Rifāáa al-Ṭahtāwī and Muhammad 'Abduh (1849-1905) and many others. In 189o, Zakī was nominated as a member of the Royal Egyptian Geographic Society (established 1875). Through his close contact with the Institut d'Égypte he developed good ties with the well-known French Egyptologist Gaston Maspero (1846-1916), then Director-General of the Department of Antiquities in Cairo, and other Egyptologists who introduced him to a wider circle of European Orientalists. ${ }^{21}$ Due to his strong talent in French-Arabic translation, Zakī was regularly invited to simultaneously translate public lectures given by European Orientalists in Cairo. ${ }^{22}$

In 1906, Zaki became the Khedive's master of ceremonies (tashrifāti), and in 1909, he was elected as a member of the Arab Scientific Academy in Damascus. Later, he became a secretary and translator of the Egyptian Council of Ministers in 1911-1921. Among Arab literati of his age, Zakī Pasha combined literary talent with his bureaucratic position in the Egyptian government. The

17 With some of his classmates, for instance, he used to go out in the evening to listen to Cairene musicians and singers till the dawn. By asking the sellers of peanuts sitting around the Square of Ibrāhīm Pasha (nowadays Opera Square) downtown in Cairo, Aḥmad Zakī and his classmates would know exactly where each singer had their shows in the city on that evening. Back to school in the early dawn, other classmates inside the school would assist them climb up the school fence-wall by using bed sheets. Interview Zakī Pasha, Al-Ahrām, 18/8/1934; cited by al-Jundī, Aḥmad Zakī, 29-30.

18 Al-Jundī, Ahmad Zakī, 18.

19 Khayr al-Dīn al-Ziriklī, Al-A đāam, Beirut: Dār Al-'Ilm lil-Malāyīn, 15th edition, 2002, vol. 6, 300-301.

$20 \quad$ Al-Jundī, Ahmad Zakī, 33.

21 Al-Jundī, Ahmmad Zakī, 11.

22 Al-Jundī, Aḥmad Zakī, 33-34. 
position enabled him to travel, visit royal and public libraries in Europe, and attend several academic congresses. ${ }^{23}$

The establishment of the Egyptian University in Cairo in 1908 marked a new episode of Orientalist-Arab encounters in the early twentieth century. Zakī Pasha played an important role in its early initiation. Prince Fu'ād (later Khedive) was nominated as rector (1908-1913) and Zakī Pasha became its secretary and lecturer in Islamic history. ${ }^{24}$

During the inauguration ceremony of the Egyptian University, Zaki Pasha gave a lecture on the glory of Islam, which Sa'd Zaghlūl heavily criticized. He considered Zakī Pasha's talk during the opening as "bending one's ear; far from the subject-matter; and empty of any good taste-especially when he spoke about Islam and its glory in an excessive way. It was not proper to deliver such a speech during the opening of a university that had no 'religion' except science." 25

One of Zakì Pasha's students at the university was the well-known Egyptian scholar Ṭāha Ḥusayn (1889-1973). Ṭāha Ḥusyan remembered Zakī Pasha’s first lecture in Islamic civilization and the new academic environment as a surprise compared to Husyan's former experience at the traditional religious university of Al-Azhar:

The professor did not say when the study began: "The author-God have mercy on him - said ...". He broached the subject by speaking for himself, not reading from a book. What he said was clear and needed no explanation, being straight forward and lucid and free from qanqalah, or citation and counter-citation, obviating mere contention. How altogether strange and new it all was, exciting my mind and revolutionizing my whole way of thinking. ${ }^{26}$

Despite this admiration for his erudition, Ḥusayn did not appreciate Zakīs "roughness" in treating his students. ${ }^{27}$

\footnotetext{
23 Al-Jundī, Aḥmad Zakī, 23-25.

24 Donald Malcolm Reid, Cairo University and the Making of Modern Egypt, Cambridge University Press, 2002, 30-31.

25 'Abd al-'Aẓīm Ramaḍān (ed.), Mudhakkirāt Sa'd Zaghlūl, Cairo: al-Hay’a al-Mișriyya al-Āmma li al-Kitāb, 1988, vol. 2, 826.

26 Reid, Cairo University, 59. Țāha Ḥusayn, Al-Ayyām, Cairo: Al-Ahrām Centre for Publication and Translation, 1992, 312-313.

27 Due to his blindness, Husayn used to go to the university in the company of a black guide. When the guide was not admitted to the campus one day, Husayn approached Zakī Pasha for his support to obtain an exemption for his guide, he replied to him roughly: "order
} 
As a prolific writer, Zakī Pasha placed himself among many other literati who participated in the revivalist movement of Arabic scholarship in the colonial age. He edited a number of what had been almost forgotten Arabic manuscripts in European and Eastern libraries on history, geography and literature, and published hundreds of articles, especially in the Egyptian newspapers al-Ahräm, al-Muqtataf and al-Hiläl. One of his most important contemporaries was Aḥmad Taymūr Pasha (1871-1930), who, unlike Zakī Pasha, was a wealthy and elite bibliophile who dedicated his fortune to books and manuscripts. ${ }^{28}$ Zaki Pasha inherited the fortunes of his wealthy wife and brother, which he used to travel, collect and buy rare books and manuscripts. ${ }^{29}$ Unlike Taymūr Pasha, Zakī Pasha often made a point of publicising his literary discoveries to the press. ${ }^{30}$ In a lecture in Cairo, the Syrian writer Muhammad Kurd 'Alī (1876-1953) compared the two Egyptian "Aḥmads" as follows: Ahmmad Taymūr was marked by religious zeal, whereas Zakī Pasha had a more worldly inclination. This made Zakī Pasha "mustshriq sharqì (an oriental orientalist)", while Taymūr Pasha remained an "oriental before anything."31 Zakī chose to mingle with society to widen his perspectives, but Taymūr preferred to remain in his isolated circle of elite people in order to preserve his "peaceful" world of literary work without any "social disturbance." Kurd 'Alī maintained that Zakî̀s "democracy" was evident in his joyful life, whereas Taymūr's "aristocracy" was marked by an austere and gloomy life. Regarding their education, Taymūr received his knowledge from religious teachers, unlike Zakī. "Therefore Taymūr became an Islamic scholar before anything, who likes to benefit from the production of the people of the West; whereas Zaki is an Oriental scholar who looks like the scholars of the West to a great degree."32 It is true that Zakī Pasha's close collaboration with European Orientalists is unique, but

is order; and what shall we do if God destines your friend not to attend the lectures!" Husayn, Al-Ayyām, 344.

28 Arthur Goldschmidt, Biographical dictionary of modern Egypt, Lynne Rienner Publishers, 2000, 211.

29 Al-Jundī, Ahmad Zakī, 38.

3o Al-Jundī, Aḥmad Zakī, 21.

31 Al-Jundī, Ahmmad Zakī, 120-121.

32 Kurd 'Alī as quoted by al-Jundī, Aḥmad Zakī, 121. Regarding his contact with Kurd 'Alī, see the letters by Muhammad Kurd 'Alī, Papers Aḥmad Zakī Pasha, National Archives of Egypt, 5016-ooo449. In 19oo, Zakī Pasha became almost deaf. He described his deafness as if it had made him eighty years old while he was still young. However, he stated that, "God had destined me to this [...] in order to keep me away from vain/false talks which became spread by and among people." Al-Jundī, Aḥmad Zakī, 273. 
his contributions to the revival of Arabic literature, philology and culture are manifested prominently in his legacy of published works.

\section{Orientalists: Disseminators of Arab Culture and Civilization}

Zaki Pasha appreciated the scholarly efforts of European Orientalists in studying Islamic history and their meticulous editing of Arabic works. Their diligence in scholarship revived a spirit of hope for him in preserving Oriental treasures. Their careful study of Arabic and Islamic history motivated his own search for Arabic classics. His house in Cairo became known as Dār al-'Urūba (House of Arabism), where he received Arab and Western orientalist guests, either those living or visiting Cairo. He was keen on reconciling Eastern and Western scholarly elites that could have positive impact on improving EastWest relations in the long term; and on creating new spaces of trust between the two factions. One of these gatherings, for example, included, on the Orientalist side, such scholars as David Samuel Margoliouth (1858-1940), Enno Littmann (1875-1958), Ignazio Guidi (1844-1935), and Carlo Alfonso Nallino (1872-1938); and on the Arab side, Sheikh Muhammad Rashīd Rị̣ā, Aḥmad Shafīq Pasha, Sheikh Surūr al-Zankalūnī, Ahmmad Shawqī, the Egyptian feminist Hudā Sha'rāwī (1879-1947), and the Lebanese-Palestinian poet May Ziade (1886-1941), along with many others. In that meeting he made it clear that "the cure of all spreading diseases [between the East and the West] will be only achieved by such Western intellectuals of pure morality and living innermost who disentangled themselves from personal whims." ${ }^{33}$

The Egyptian press followed Zakī Pasha's encounters with orientalists with a degree of enthusiasm. For example, the Egyptian newspaper al-Mu'ayyad described his visit to the Congress of Orientalists in Athens in 1912 as follows: "the lobby of the hotel where he stayed became a kacba to which many people, whom he knew and whom he did not know, visited him. They were pointing at him, saying: this great Egyptian scholar. All the poets, literati and journalists in Athens had come to see him." ${ }^{34}$

Zakī Pasha made use of his contacts with Western scholars to enrich his library with rare books. In Europe, he took every opportunity to see and photograph old Arabic and Islamic manuscripts and primary sources in various libraries. Although he was officially dispatched to Europe to represent the Egyptian government to the Orientalist congress in London, the principal

33 As quoted in al-Jundī, Aḥmad Zakī, 238.

34 Al-Mu'ayyad, 9 April 1912 cited in al-Jundī, Aḥmad Zakī, 107. 
aim of his visit was to collect primary sources and to witness and document his observations of Islamic architecture and relics in Spain and Portugal. ${ }^{35}$ At Zakī Pasha's request, the Egyptian Khedive allowed funding for his travels to Spain after the end of the congress in order to study its past and present civilizations. ${ }^{36}$

\section{The Congress of Orientalists in London: Love and Transparency, or Trustworthiness and Loyalty}

Zakī Pasha's attendance of the Congress of Orientalists in London in 1892 marked a shift in his scholarly career. In that year, the then 24-year-old Zakī travelled to London to attend that congress as a representative of the Egyptian government. It was the same year that the young Khedive 'Abbās Hilmī II (1874-1944) had assumed the throne of Egypt after his father's sudden death. Zaki Pasha was keen on combining his duty of attending the congress with the discovery of other peoples in terms of work, life, sciences, upbringing, manners, beliefs, luxury, sufferings and inventions. ${ }^{37}$

In the beginning, some Egyptian officials objected to Zakī Pasha's nomination to represent Egypt to this congress because of his young age. In the farewell meeting in Alexandria before his departure, Khedive 'Abbās Hilmī considered the selection of Zakī Pasha as the best choice for that duty by praising him as "a genius of a young man with whom we could prove to the scholars of Europe that we have youth who are able to join them in al-fadll wa al-irfän (virtue and knowledge)."38

Zaki Pasha realised that the nineteenth century had seen the emergence of new transportation methods and more affordably priced travel. For him, new means of travel broadened the human mind by enabling people to examine the ideas of other peoples which had "undeniable benefits." ${ }^{39}$ During the visit, he toured around several European cities in six months (14 August 1892-14 February 1893). He proudly told his readers that he endured Europe's hot and cold weather, which "an oriental could not bear on a first visit to Europe like him."40

\footnotetext{
35 Zakī, al-Safar, 450-451.

36 Zakì, al-Safar, 452 .

37 Zakī, al-Safar, 14.

38 Zakī, al-Safar, 20.

39 Zakī, al-Safar, 29.

40 Zakī, al-Safar, 445, After their return, the Egyptian Official Gazette al-Waqä’' ${ }^{\prime}$ al-Mişriyya (Egyptian Affairs) celebrated the delegation of Zakī and Sheikh Rāshid to one of the most important scholarly congresses in Oriental Studies (13 March 1893). Zakī, al-Safar, 448.
} 
In the company of Sheikh Muhammad Rāshid, another Egyptian official representative to the congress, Zakī Pasha began his first journey in Greek cities, and then passed by Rome, Florence and Pisa. Besides monuments, museums and churches, he was keen on visiting universities and libraries of these cities. At the University of Pisa, for example, he was impressed by its library, especially the book lending services. He recorded that every book had a piece of wood that was exactly the same form and size, bearing its title and serial number. This piece of wood was put in the place of every lent book in order to keep the books upright in their ordered places on the shelves; and to inform other readers that the book was not available. He also saw that issues of scholarly periodicals were kept in boxes that were made in the shape of a book in order to preserve the monthly issues till they were bound in annual volumes. ${ }^{41}$

On August 27, 1892, he arrived in Paris which he considered as jannat alJanāin (the paradise of all paradises) in the form of a city. ${ }^{42} \mathrm{~A}$ few days later, he arrived in London; by then he discovered that if Paris were jannat al-duny $\bar{a}$ (the paradise of this life), London should be mawsū āt al-'älam ("the encyclopedias of the world"). ${ }^{43}$ In London, he stayed at the luxurious Albemarle Hotel and was impressed by the hotel's electric lighting. ${ }^{44}$ Zaki Pasha and Sheikh Rāshid were welcomed by Field Marshal Francis Wallace Grenfell (1841-1925), former Commander-in-Chief of the Egyptian Army in 1885. The delegates to the congress assembled in the theatre of the University of London on 5--12 September under the presidency of Friedrich Max Müller (1823-1900). Scholars and delegates of eleven governments, twenty-seven learned societies, and thirteen universities attended the congress. In the evening, the 1st Earl of Northbrook (1826-1904), former Viceroy of India (1872-1876) and a VicePresident of the congress, invited Zakì Pasha with a select group among the participants for a gala dinner at his private residence. Zakì Pasha was proud to be the only invited "Oriental" guest at that dinner where he sat between the Austrian orientalist Hofrath Buhler and Grenfell.

Zakī Pasha was elected as a member of a committee to discuss the congress' organization in the following year. In the committee, Count de Gubernatis proposed to convene the congress every three years in order to give participants enough time to prepare their research papers. Zaki Pasha was of the view that the plan to have the Congress every three years was principally initiated

\footnotetext{
41 Zakī, al-Safar, 55-56.

42 Zakī, al-Safar, 87.

43 Zakī, al-Safar, 103.

44 Zakī, al-Safar, 103.
} 
because there had been a limited number of orientalists in the past. Because their number was increasing worldwide, he thought it would be more effective to organize the conference every two years. The members finally agreed that the next congress would take place in 1894 in Geneva. ${ }^{45}$

Zakī Pasha was good at French and Italian but knew little English. During the congress, he presented an account, in French, of several works composed or copied by him on the Qurān and the order of surās, Arabic glossaries as well as historiographical works. ${ }^{46}$ His Egyptian colleague Sheikh Rāshid spoke, in Arabic, on the history and characteristics of the Cairene dialect, and presented his new commentary on Maqāmāt al-Harīri by the grammarian and lexicographer al-Ḥarīīi (1054-1122).

In the context of his plea for cooperation between al-mustashriqin (orientalists) and scholars in the Orient, Zakī Pasha interchangeably used the words mashriq and sharq to refer to the "East/Orient" on the one hand, and maghrib and gharb to refer to the "West/Occident" on the other. In his address to the congress, he praised the works of orientalists in changing the "Western public mind" about the East, and in removing the barriers created by the people of "blind fanaticism" between the "twins" of the East and the West. ${ }^{47}$ This advantage was due to the scholarly familiarity between Western and Eastern scholars in such gatherings as this congress:

You know that your people were ignorant about the value of what we have and judged us on the basis of what we are innocent of. [Due to] scientific familiarity, they [people in the West] now started to discover what al-älam al-Islämì (the Muslim World) possessed as a splendid system of rites emanating from the innermost purity. You are sincere in your al-wudd wā al-șafä' (love and transparency), just as we give you trustworthiness and loyalty. ${ }^{48}$

Zakì Pasha was aware of the aloofness and lack of cooperation between European orientalists and their Arab and Muslim counterparts in the East. In his lecture, he highlighted the role of Arab men of letters whose works were undervalued due to the "anonymity" of their works or their "lack of luck in life." 49 Therefore, he recommended the organization of a future congress of

\footnotetext{
45 Zakī, al-Safar, 104-106.

46 Zakī, al-Safar, 457-484.

47 Zakī, al-Safar, 453-454.

48 Zakī, al-Safar, 454.

49 Zakī, al-Safar, 455 .
} 
orientalists in the East in order to enable distinguished indigenous scholars in the colonial regions, who had no financial means to travel to Europe, to participate in this scholarly endeavour: "By this, a larger group of [Eastern scholars, who are] good at investigation and scrutiny would join [your] community that is at the forefront of supreme ideas and noble aims; $[\ldots]$ and therefore orientalists could benefit greatly from the help and cooperation of [Eastern scholars]."50

On the last evening, about 130 foreign members were invited to a banquet at Hotel Metropole. As Chair, Sir M.E. Grant Duff (1829-1906), a Scottish politician and former administrator in India, proposed a toast to the "Ninth International Congress of Orientalists," by ascribing its success to

the presence of so many distinguished scholars of different nationalities, who, undeterred by the outbreak of cholera on the Continent, and the consequent difficulties in the way of travelling, had come long distances to attend our gathering. Austria-Hungary, France, Germany, Holland, Italy, and many other countries, to say nothing of India and other distant but most important parts of the British Empire, had been admirably represented. ${ }^{51}$

Zakī Pasha compared the gathering with the "Tower of Babel" due to the various languages spoken at the table during that evening. ${ }^{52}$

\section{British Cities: Discovering the "East in Europe"}

Zaki Pasha's trip to Europe enabled him to discover the "East" in Europe. During the days of the congress, he had the chance to recreate and visit typically English garden parties in London. After the congress (on 13 September) he and Sheikh Rāshid were invited by the manuscripts and art collector Lord William Amhurst Tyssen-Amherst, 1st Baron Amherst of Hackney (18351909) to his country home in Didlington in East Anglia. ${ }^{53}$ Tyssen-Amherst

50 Zakī, al-Safar, 455 .

$51 \quad$ E. Delmar Morgan ed., Transactions of the Ninth International Congress of Orientalists held in London, 5 th to 12 September 1892, London: Committee of the Congress, 1893, iviii-lix.

52 Zakī, al-Safar, 107.

53 See Theophilus G. Pinches, The Amherst tablets: being an account of the Babylonian inscriptions in the collection of the Right Hon. Lord Amherst of Hackney, F.S.A. at Didlington Hall, Norfolk, London: Quaritch, 1908; Bernard P. Grenfell \& Arthur S. Hunt, The Amherst 
was famous for his collection of ancient Egyptian artifacts preserved in his house. Zakī Pasha met Tyssen-Amherst at the congress with the latter's wife and four of his daughters. ${ }^{54} \mathrm{He}$ was fascinated by the garden, trees, lakes, birds and the small factories and small arms storage next to Tyssen-Amherst's estate. In his garden, Amherst collected rare plants and had a small design of the Alhambra in his house. In the house, Zakì Pasha saw a large number of ancient Egyptian and Babylonian artifacts, including 13 boxes of ancient Egyptian materials discovered in a tomb in Tal al-Amarna in Southern Egypt. In his private library, Tyssen-Amherst kept a large number of rare and amazing Quranic manuscripts, as well as Arabic, Persian, and Western manuscripts and papyri which he protected with a security system. Zakī Pasha appreciated the generosity of Tyssen-Amherst, his wife and six daughters, two or three of whom had already visited Egypt and were able to write and read a few words of Arabic. ${ }^{55}$

After London, Zakī Pasha visited Birmingham, Derby, Manchester and Liverpool. In Liverpool, he visited the British convert to Islam Abdullah Quilliam (1856-1932) and his Liverpool Muslim Institute..$^{56}$ He saw how he and other British Muslims were keen on fulfilling their Islamic religious duties in the small mosque in a house, that accommodated around a hundred Muslims. In the same building, they established a Muslim college, which offered courses in British literary subjects, combining them with Islamic values. Zakī Pasha noted that the converts were friendly to each other and used to greet each other in Islamic formulas. They were about 60 converts, including women, and

Papyri: being an account of the Greek papyri in the collection of Lord Amherst of Hackney, Didlington Hall, Norfolk, London: s.n., 1900-1901. A good part of his remaining papers exists at the Bodleian Library and the British Archives in Kew, see http://www.bodley.ox .ac.uk/dept/scwmss/wmss/online/1500-1900/tyssen-amherst/tyssen-amherst.html; http://discovery.nationalarchives.gov.uk/details/c/F65318 (accessed on 10 April, 2017). For more about the family, see, http://landedfamilies.blogspot.nl/2014/05/122-tyssen-amherst-later-cecil-of.html (accessed on 10 April 2017).

54 Morgan, Transactions, p. xix.

55 Zakī, al-Safar, 108-111. One of Tyssen-Amherst's daughters, Alicia Amherst (1865-1941) became a famous historian of English gardening; her father's garden seems to have had a major effect on her since her childhood. See Alicia M.T. Amherst, The History of Gardening in England, Barsinghausen: Unikum-Verlag, 1896. She published many books and articles under the name Mrs. Evelyn Cecil or Lady Alicia Rockley. See Twigs Way, Virgins, Weeders and Queens: A History of Women in the Garden. Stroud: The History Press, 2006.

$5^{6}$ Zakī, al-Safar, 178-179. About Quilliam and his Liverpool Muslim Institute, see Ron Geaves, Islam in Victorian Britain: The Life and Times of Abdullah Quilliam, Markfield: Kube Publishing Ltd, 2010. 
Zakī Pasha had expected they would one day spread Islam in Britain. He prayed the Ishä' Prayer with them. In their gatherings, they recited some translated Qurānic verses in the form of poems. ${ }^{57}$

After a short visit to Chester and a coal mine in Chirk in Wales, he returned to London. There again he was pleased to see oriental arts in Europe in the exhibition of Egyptian and oriental artefacts at the Niagara Hall in Westminster. During that time, a special exhibition was made to commemorate the ancient Egyptian capital Memphis through a portrayal of ancient Egyptian life, temples, trees, the Nile, pyramids and the Sphinx. As the organizer was also a member of the Congress of Orientalists, Zakī Pasha was offered a special tour. He met a certain al-Mu'allim Ilyās Layān Hilawā, who excelled in oriental woodcarving; and whom Niagara Hall hired for his fineness and mastery of this type of art that was presented during a following exhibition in Chicago. Zakī Pasha bemoaned that people in the Orient had almost forgotten such types of art, whereas Western nations boasted at excelling in their own manufactures with their government's support. ${ }^{58}$

Back in Paris, Zaki Pasha gave a detailed description of the city, garden, parks, restaurants, theatres, squares and people. In the Imprimerie Nationale, ${ }^{59}$ he was fascinated by its "magnificent" printing work, typesetting, binding, engraving photographs and drawings, which were made by over 1200 workers, men and women. He saw a statue of Johannes Gutenberg erected as a symbol for printing. Zaki Pasha thought it was remarkable that of the 288 letters used for printing, 153 were specially designed for non-Western languages, facilitating printing into 58 Oriental languages, including Arabic. ${ }^{60}$

\section{Lost Islamic Glory in Spain}

On 19 November, Zakī Pasha left for Spain through Tour, Angoulême and Bordeaux. After twenty-four hours on the train, he arrived in Irun at the Spanish border, remembering the vanished Islamic glory of Spain, and silently recalling the famous poem of the Andalusian poet al-Rundi (1204-1285) that lamented the Fall of Seville in 1267. Zakī Pasha's sad feeling during that visit to Spain was,

\footnotetext{
57 Zakī, al-Safar, 178-179.

$5^{8}$ Zakī, al-Safar, 218-219.

59 It was open for the public on Thursdays at $6 \mathrm{pm}$ with special permission from its director. See Zakī, al-Safar, 358. See also Gwladys Longeard, "L'Imprimerie nationale pendant la Commune de 1871," Revue d'histoire moderne et contemporaine 1/2005 (No 52-1), 147-174.

6o Zakì, al-Safar, $35^{8}$.
} 
as Yaseen Noorani puts it, "a vision of cultural renaissance that negates the present political reality and elaborates a truer one that supersedes it." 61

In Spain, he took a tour in Irun where the buildings, streets and lanes appeared to him like Egypt in many ways. While in Paris, he had learnt some Spanish, but discovered that it was not helpful for him in communicating with Spanish people. He switched between French and Italian, and sometimes used hand gestures. Despite the hard journey and his image of the Spanish people as "discriminating" to Muslim visitors, Zakī Pasha was ready to endure the experience. He boasted that he would be the first Egyptian Muslim of his generation who would visit and write about Spain. ${ }^{62}$

After visiting Fontarabia, San Sebastián and Pamplona, he arrived in Saragossa where he was struck by its people's good manners and hospitality. There he saw a unique collection of Arabic books and started to improve his Spanish. He was invited to a meeting at the Academia Juridico Literaria by its president Pablo Gil and another member, San Pio, who was also Zakì's Spanish teacher. Then he was elected as honorary member of the Academia Juridico Literaria in Saragossa and addressed his first meeting with them on Spanish civilization under the Arabs by using his memory and depending on the sources that he borrowed from Spanish Arabists in the town. The Academy translated the lecture into Spanish, and some of the scholars in the academy gifted him with some of their works. In Pablo's private library, he saw many books in Aljamiado that were written in Arabic scripts. He also saw many such manuscripts in Saragossa and Madrid, including Qur’ān copies in Aljamiado. ${ }^{63}$

Before his arrival in Portugal, Zakī Pasha toured around other Spanish cities, such as Castejon, Miranda, Burgos, Avila and finally Madrid. In Madrid, he met several Spanish scholars, politicians and diplomats, including the Ottoman ambassador to Madrid Tarkhan Pasha, who later became Minister of Foreign Affairs. Zakī Pasha praised the consul for his wide knowledge and excellent command of several languages which gave him a prominent status in European political circles. Zakī Pasha hoped that the Sublime Porte should nominate such people who cherished Islam and their nation to such diplomatic posts in

61 Yaseen Noorani, "The Lost Garden of al-Andalus: Islamic Spain and the Poetic Inversion of Colonialism", International Journal of Middle East Studies, 31/ 2 (May, 1999), 237-254.

62 Zakī, al-Safar, 378-382.

63 He notes that the word Aljamiado originated from the word 'ajamī (non-Arabic), which the Arabs used as referring to any foreign language. When the Arabs lost their territories in Andalusia, Arabic was replaced by Castilian Spanish, but the Arabs started to write Spanish with Arabic script. As the Spanish could not pronounce the sound ' $a$, it became Aljamiado instead of 'ajamī. Zakī, al-Safar, 384-386. 
Europe. In Madrid, on Columbus Day he watched corrida de toros (bullfighting) three times. He asserted that the Arabs had excelled in this sport of fighting in Andalusia as well. Later in Lisbon, he visited the National Library, School of Engineering and the National Museum. Due to Zakī Pasha's official status, he was received at the court of Carlos I of Portugal (1863-1908). ${ }^{64}$

After returning to Madrid, Zaki Pasha became ill due to an influenza pandemic in that year which affected many people in Europe. However, he and the Ottoman Consul were invited to the court of the Spanish Queen Maria Christina of Austria (1858-1929), the widow of King Alfonso XII of Spain, who succeeded him as regent until her son Alfonso XIII attained his majority in 1902. Zaki Pasha was happy that the queen had given them twenty minutes of her time during which they discussed issues related to the Arabic language and Arab influence in Spain. ${ }^{65}$ It is worth noting that Zakì Pasha published an obituary of the queen after her death in 1929 in the Egyptian daily Al-Ahräm in which the 61-year-old Zakī Pasha recollected his visit to her court as a young man. The queen was taught some Arabic by her interpreter and advisor to Moroccan affairs the Spanish Arabist Eduardo Saavedra (1829-1912), who was also a friend of Zakī Pasha. She learnt Arabic particularly to negotiate mutual relations with a delegation of Moroccan notables dispatched to Madrid by the Sultan of Marrakesh. The queen was told by Saavedra that every one of them was carrying a copy of the Quran in a silk case on the left side of the chest. She surprised the delegation by telling them that she knew Arabic, but the delegates did not believe it in the beginning. In order to convince them, she asked them to show any of the copies of the Qurann which they carried. But because she was not a Muslim and was not in a state of purity to touch the Qurann according to the Islamic scriptures, they were not ready to place the book in her hands. The head of the delegation evaded the dilemma by holding the Qur'ān open before the queen's eyes without her touching it. Having looked into the pages with her hands behind the back, she could recognize and count the name of "Allah" on the open pages. ${ }^{66}$

\footnotetext{
64 Zakī, al-Safar, 390-393.

65 Zakī, al-Safar, 406.

66 Another anecdote is related to the child prince. In order to escape the punishment of being detained in his room by his mother, he opened the window and started to scream: "Viva the Republic." Another story was that once she invited a group of foreign ambassadors and notables to an official dinner in her palace, but her cooking staff went on a strike. In order to solve the problem, she supervised her daughters and other maidens in the palace's kitchen and prepared the meal by herself. Al-Ahräm, 9 February 1929.
} 
During their conversation on Arab civilization, Zaki Pasha looked at the queen as if she were an heir of such knowledgeable Muslim philosophers and scholars in Spain as Ibn Țufayal, Ibn Rushd or Ibn Hazm. The queen was also interested to hear about the pyramids and the discovery of the pharaoh's tomb in the Amarna archeological site in Egypt in 1892, parts of which Zakì Pasha had already seen in Tyssen-Amherst's collection in England. At the end of the meeting, the queen decorated him with an honorary badge which he boasted of by saying: "with this the Arab Muslim sharif (noble) became one of the knights of the Catholic Isabella at the hands of the Spanish Queen Christinamay God rest her soul in mercy." 67

In January 1893, he visited Seville, Cordoba and Granada. In Alhambra, he signed the visitors' book as the "representative of the Egyptian government to the ninth Congress of Orientalists," expressing his sorrow about how this space was no longer Islamic. ${ }^{68}$

After his return to Egypt, Zakī was invited to 'Abdīn Palace to meet Khedive 'Abbās II. He presented the Khedive with the collection of books given to him by Spanish scholars, and photographs of sites in old Islamic Spain, including a photo of the painting of La Rendición de Granada (The Surrender of Granada) by the Spanish painter Francisco Pradilla Ortiz (1848-1921), which was commissioned by the Spanish Senate in 1882. Zakì Pasha also submitted a detailed report of the trip and presented a few of his translated books to the Khedive. ${ }^{69}$

\section{Paris World Exhibition: A “Civil hajj” in Europe}

In 1900, Zakī Pasha documented his third visit to Europe, when he combined a medical visit to Europe with attending the Paris World Exhibition. Regarding his second visit to Geneva in 1894, he did not document it to his public readership, since he preferred to keep the experience to himself. His national duty had now obliged him to share his third visit with his Arab readers, which coincided with the Paris World Exhibition. ${ }^{70} \mathrm{He}$ named his Parisian travelogue al-Dunya fi Paris (The World in Paris), denoting that through hosting the exhibition, Paris brought the world in one city together.

\footnotetext{
67 Al-Ahräm, 9 February 1929.

68 Zakī, al-Safar, 406.

69 Zakī, al-Safar, 451-452.

7o Zakì, al-Dunyā fì Paris, Cairo, 190o, 4.
} 
Zaki Pasha was not the only Arab visitor to the Paris exhibition that year. Egyptian, Syrian and Tunisian Arab visitors, both Christians and Muslims, were at the exhibition as well. ${ }^{71}$ These travelers were sometimes sent by their governments either as official representatives, or to report on Western cultures that were on display at the World Fairs. ${ }^{72}$

Against the advice of his friends and family, Zakī Pasha embarked on his voyage on Friday 13 April 1900, ${ }^{73}$ which was believed to be the unluckiest day of the calendar, according to a superstition that arose in the late 19th century. After his arrival in France, he went to Villefranche-sur-Mer, which he, unlike many Arab visitors to Europe, preferred above capital cities for its healthy climate and natural food. ${ }^{74}$ After returning to Paris, he was surprised to find frogs on the menu, but he finally tried the dish after hesitating for a while. Zaki Pasha found no religious harm in eating frogs, comparing them with shrimps and crabs which are allowed in Islam. He humorously advised his readers that they should try frogs or at least frog soup if they ever visited Paris in order to "enjoy the pleasure of life," as he did. ${ }^{75}$

Zakì Pasha was impressed by the preparatory work for the exhibition, which he described as al-hajj al-madani al-mukhtalaț (mixed civil pilgrimage) in Europe. ${ }^{76} \mathrm{He}$ proudly gives a detailed description of the Egyptian department in the exhibition and its opening by the Egyptian Prince Muhammed 'Alī (18751954) and other Egyptian, Arab and European dignitaries in Paris. In the Islamic section, there was a certain Khawāja Tawfìq Shalhūb, a Syrian employee of the Iranian Consulate in Alexandria, sitting at the entrance in an Azharite religious

71 As quoted in Newman, "Myths and realities", 57-65. Muhammad Ibn al-Khūja (d. 1325/19078), Sulūk al-Ibrìz fi Masālik Barīz, Tunis: al-Mațba'a al-Rasmiyya, 19oo; Muhammad Ibn 'Uthmān al-Hashāishī (1855-1912), Wașf Ma'raụ Barīs, 1900; Nasīm Khallāṭ (18331901), Siyāha fi al-gharb Urūbbī, Cairo: Mațba'at al-Muqtațaf, 19o1; Muḥammad Labīb al-Batanūnī (d. 1938), Riḥlat al-Ṣayf ilā Urūbbā, Cairo: Mațba'at al-Liwā', 19o1; Muhammad Tawfìq al-Bakrī (1870-1932), Sahārīj al-Iu’lu', Cairo: Maṭba'at aI-Hilāl, 19o6; Muhammad al-Muwaylihi (1858-1930), Hadīth Isa b. Hishām aw fatra min al-Zamān, 4th ed., Cairo: Mațba'at Miṣr, 1927, 375-462. See also, Fahd Nayif al-Dabus, al-Raḥhāla al-Arab wa Intiba'atuhum 'an al-ma'ārị̣ al-dawliyyaI, 1851-19oo, Kuwait: Dabus Center, 2009.

72 Newman, "Myths and realities", 31.

73 Zakī, al-Dunyā, 5 .

74 Zakī, al-Dunyā, 20-21.

75 Zakī, al-Dunyā, 27-28.

76 Zakī, al-Dunyā, 44. He reported a very unfortunate accident that took place during the repairs of a temporary plaster footbridge, which left nine people dead and injured forty. On the next day, another accident happened where an Egyptian worker in the Egyptian department of the exhibition was severely injured. Zakī, al-Dunyā, 43. 
uniform and turban asserting to be an Azhari Sheikh under the name Sheikh Tawfiq. This Tawfiq offered non-Arab visitors to write their names in Arabic as a souvenir and money for their visit to the Egyptian section. Zaki Pasha was surprised that he, by snatching this opportunity, was able to earn much money every day without anyone preventing him. ${ }^{77}$

What attracted his attention most was the exhibition of dogs and their luxurious accessories, and how the Europeans had reached a high standard of living to take care of these animals and consider them part of their fortunes. By this example, he saw that "people in Europe and America reached an incredible degree of luxury and elegance. Wealth poured on them because of their hard work and effort to the extent that they do not know what to do with it [wealth]. May God give me one, two or three of these dogs so that I can sell them and relieve myself from pain!"78

\section{Revival of Arabic Literature}

Zakī Pasha made use of his position in the Council of Ministers, travels and international contacts to achieve many goals in serving the study of Arabic literature, by photographing and editing old unique manuscripts in the fields of religion, philology, literature, geography and history. ${ }^{79}$ After he had become a secretary general of the Council of Ministers in 1911, he launched his wellknown project of Ihya $\bar{a}^{c} a l-\bar{a} d \bar{a} b$ al-'arabiyya (the Revival of Arabic Literatures) funded by the Egyptian Ministry of Education, which marked the most fruitful stage of his career. It was mainly inspired by the works of orientalists in editing classics of Arabic and Islamic civilization. He pushed for similar scholarly enterprises in Egypt, and not merely waiting for orientalists to discover the "glory" of the Arab past. ${ }^{80}$ Following Zakī Pasha's recommendations, Aḥmad Hishmat Pasha (1858-1926), then Egyptian Minister of Education, agreed to fund the edition and publication of twenty-seven rare Arabic manuscripts at the former's own disposal. The Council of Ministers accepted the proposal (September 15, 1911) and the task was put under the direct supervision of the Council of the National Library. The project launched the publication of

\footnotetext{
77 Zakī, al-Dunyā, 93-95.

78 Zakī, al-Dunyā, 99-103.

79 For example, in order to guarantee a wider accessibility of books to Egyptian readers, he succeeded in obtaining a permit from the Egyptian government to remove custom duties from books coming from abroad. Al-Jundī, Ahmad Zakī, 115 .

$80 \quad$ Al-Jundī, Aḥmad Zakī, 127.
} 
the encyclopedia of the Mamlūk period by the Egyptian historian and civil servant al-Nuwayrī (1272-1332), Nihāyat al-arab fí funūn al-adab (The Aim of the Intelligent in the Art of Letters), ${ }^{81}$ and Ibn Faḍl Allāh al-'Umarī's, Masālik al-Abșār fì Mamālikal-Amșār (Paths to Discernment into the Kingdoms of the Developed Places). ${ }^{82}$

Zakī Pasha made use of his wide network of associates to search for new sources of similar manuscripts of the subject. In 1911, Josef Horovitz (1874-1931), the German Jewish orientalist, informed Zaki Pasha that a full manuscript of Nihayyat al-arab was in the possession of the family of Samih Abila, whose father was a British consul in Sidon. ${ }^{83}$ As he was keen on connecting history with the contemporary period, Zakī approached the director of the province of Banī Suwayf in order to provide him with information about al-Nuwayriyya village, the birthplace of the author. In 1902, the village counted 3,500 inhabitants, 500 houses, 90 literate people, one school of 20 pupils and 3 Qurānic schools of 20 pupils, and one large mosque. ${ }^{84}$ Moreover, when he visited Palestine in the 1920s, he took a draft of Masālik al-Abșār in order to read it with Palestinian archeologists and compare al-Umarìs description of the city with their knowledge. 85

The project financed the publication of almost fifty-five titles, but it slowed down and later completely stopped. According to Kurd 'Alī, one of the reasons for the delay was Zakī Pasha's perfectionism and lack of confidence in the editing work of other people. Finally the Egyptian government withdrew the rest of the project's budget. ${ }^{86}$

Zakī Pasha's project was criticized in some Coptic circles in Egypt. The Coptic newspaper al-Wațan ('Homeland', founded in 1877), for example,

81 The first complete edition of the text began in Egypt in 1923 by Ahmad Zakī Pāsha and completed in the 196os, but its final volumes were only published in 1997. Shihāb al-Dīn Aḥmad b. 'Abd al-Wahhāb al-Nuwayrī, Nihāyat al-arab fífunūn al-adab, eds. Aḥmad Zakī Pāsha et al, Cairo: al-Mu’assasa al-Mișriyya al-'Āmma li-'l-Ta'līf wa-'I-Tarjama wa- 'l-Ṭibāa wa-'I-Nashr, 1923-97. Letter of the Minister of Education, 23 October 1910. National Archives of Egypt, Papers Ahmad Zakī 5016-0oo449. For a study of al-Nuwayrì's encyclopaedia, see Elias Ibrahim Muhanna, The World in a Book: Al-Nuwayri and the Islamic Encyclopedic Tradition, Princeton University Press, 2018.

82 Ibn Faḍl Allah al-'Umarī, Masālik al-Abșar fi Mamālik al-Amșar, ed. Aḥmad Zakī Pasha, Cairo, 1924.

83 Letter, 16 March 1911, 51, Papers Aḥmad Zakī, National Archives of Egypt, 5016-ooo449.

84 See "Letter by the director of Banī Suwayf Governorate," n.d., Papers Ahmad Zakī, National Archives of Egypt, 5016-000449.

85 Al-Jundī, Ahmad Zakī, 61.

86 Al-Jundī, Ahmad Zakī, 6 o. 
vigorously attacked the project by stating that the government supported a return to the "backwardness" of Arabs by "adulterating its people's taste for sound literatures and useful sciences." ${ }^{\text {77 }}$ However, a few years later, Salāma Mūsā, the Coptic writer and Egyptian editor of Al-Hilāl, critically asked Zakī Pasha why he always insisted on praising ancient Arab civilization and history, which meant he would urge people to cling to the past and outdated ways of life, thereby detesting new social reforms. In his answer, Zakī Pasha reminded Musā of his Coptic origin, and that his pride in ancient Egyptian civilization never meant that Egypt in the present should be ruled by its ancient systems. Emphasizing the role of Arab civilization in history would raise the awareness of contemporary Arabs to take the example of their ancestors in progress. In this debate, Zakī Pasha disagreed with Salāma Mūsā that Islam encouraged theocratic rule. Mūsā also connected the Arab withdrawal from Spain and the Turks from Europe to the contemporary deteriorating status of Muslims and an adherence to the norms of the past. Zakī Pasha ascribed the Arab and Muslim decline and loss of Spain to a general degeneration, and not to an attachment to old traditions. The reason behind the Turkish occupation of other regions was booty, which was not a stable Islamic conquest, and it was in any case destined to vanish, in his view. Zakī Pasha disagreed with Salāma Mūsā in his aspiration to associate the Orient with the West: "if you call the Orient to be Westernized, then I likewise call the West to be Arabicised; we [both?] have our traditions and glory." 88 However, Zakī Pasha agreed that the Orient could take other strengthening aspects from the West, such as freedom of women, separation between religion and state, and the use of European inventions. ${ }^{89}$

\section{Al-Khizäna al-Zakiyya}

In 1911, Zakī Pasha obtained a permanent official permit for a special section of the Dār al-Kutub, the Egyptian National Library, to be allocated for his private collection of books and manuscripts, which became known under his name as al-Khizāna al-Zakiyya. The collection contained his books and manuscripts which he had started gathering since his student days in the 1880 ..$^{90}$ He placed it in Dār al-Kutub because he was anxious that otherwise the collection would turn into recycling packing materials to "spice or oil dealers or greengrocers"

\footnotetext{
87 Umar Ryad, Islamic reformism and Christianity, Leiden: Brill, 2009, 105.

88 Al-Hiläl, vol. 35/5, 525.

89 Al-Hilāl, vol. 35/5, 525.

go al-Jundī, Ahmad Zakī, 116.
} 
after his death; or to be sold and scattered in various places, as was the fate of the private library of the Egyptian educationist 'Alī Pasha Mubārak (18231893). ${ }^{91}$ Al-Khizāna was always open to the public every day from $4 \mathrm{pm}$ to midnight. It is said that after his office hours and having had his lunch and smoked his water-pipe, Zakī Pasha regularly continued his reading, editing work, and responding to the press in his private library. ${ }^{92}$

Zaki Pasha collected his unique library in several ways. He travelled abroad with his own box camera in order to collect and photograph Arabic manuscripts from famous royal, university or private libraries. In addition, he made use of the service of Western Arabists and private photographers in Europe to photograph rare manuscripts for him..$^{93}$ Some of Zakī Pasha's friends in Europe or Istanbul also intermediated between him and orientalists, public or university libraries and facsimile shops. They sometimes tried to fix costs or to check the quality of paper and images. For example, the Turkish lawyer Nimatullah G. Shammas (also known as Girgis Zadeh Nimatullah) was his contact person in Istanbul, providing him with many of these sources. ${ }^{94}$ 'Abd al-Hamīd Luṭ̂i, an Egyptian student under the tutelage of Maspero in Paris, collected facsimile copies of manuscripts, especially of al-Nuwayrī, from Paris, Leiden, Berlin and London. For example, Luṭì met the Dutch orientalist Christiaan Snouck Hurgronje (1857-1936) in Leiden on October 7, 1909 and requested his advice on al-Nuwayri's manuscript, held at the university library. ${ }^{95}$ Michael Jan de Goeje (1836-1909), Snouck's predecessor, had plans to edit al-Nuwayri's work, but never completed the project. In Leiden, and with Snouck's help, Luṭfi found 17 folios of al-Nuwayrìs book, one of which was probably copied by al-Nuwayrī himself. As Snouck was enthusiastic about the publication of al-Nuwayrì's work, he introduced Lutfii to the director of the university library and the publisher Brill for further help. Luṭî was positive

\footnotetext{
91 Al-Jundī, Aḥmad Zakī, 117.

92 Al-Jundī, Aḥmad Zakī, 117.

93 For example, the German orientalist and convert to Islam, Fritz Krenkow (1872-1953), letter, 31 March 1926, National Archives of Egypt, Papers Ahmad Zakī 5016-ooo449. In Spain, he made use of the service of Julian Ribera in Madrid, who photographed manuscripts in the El Escorial for him. Letter, 15 Oct. 1907, National Archives of Egypt, Papers Aḥmad Zakī 5016-000449.

94 See his letters to Zakī Pasha, National Archives of Egypt, 5016-ooo426, file 7.

95 Letter 'Abd al-Hamīd Luṭ̂i to Aḥmad Zakī Pasha, Paris 16 October 19og. National Archives of Egypt, 5016-000424. Other letters can be found in this file 6.
} 
about Dutch orientalists having "the friendliest faces and most sincere in service, especially Snouck." ${ }^{\prime 6}$

Zaki Pasha also made deals with the heirs of prominent intellectuals and public figures in Egypt. After reading an obituary of any wealthy elite person or writer in the press, he would immediately try to negotiate with the heirs to buy their deceased relative's private collection through al-Khānjī Library in Cairo. He is said to have once sold one of his pieces of land in al-Qalyūbiyya province in order to enlarge his collection. ${ }^{97}$ Kurd 'Alī reported that his friend Zakī Pasha used to appropriate half of his monthly salary for buying books and periodicals. ${ }^{98}$ When he died in 1934, his private collection had reached almost 18,700 volumes, primarily consisting of manuscripts, old maps, Arabic periodicals and orientalist editions and translations of classical works. ${ }^{99}$

In 1921, Zakī Pasha was accused of corruption, but after a short period of suspension from his job, he was acquitted from all accusations. ${ }^{100}$ During the trial, the Director of Dār al-Kutub tried to force Zakī Pasha to move the library to the upper floor of the building, which Zaki Pasha strongly opposed. He was annoyed with the Director's rough reply in which he was not addressed in the formal way

96 Letter Luṭ̂i to Zakī Pasha, Leiden 10 Oct. 19og; letter Luṭ̂i to Zakī Pasha, Paris 1 Sept. 19o9; letter Luṭ̂i to Zakī Pasha, Cairo, 21 Nov. 19og. National Archives of Egypt, 5016-000424.

97 Al-Jundī, Ahmad Zakī, 230.

98 Kurd 'Alī, "Al-Khizana al-Zakīyya," al-Muqtabas, 79, 1 Sept 1912.

99 Al-Jundī, Ahmad Zakī, 111. For more details about the contents of the library, see Kurd 'Alī, "Al-Khizāna al-Zakīyya," Al-Muqtabas, 79, 1 Sept. 1912. Regarding the collection, Zakī Pasha was not initially interested in spending money for repairing or binding worn-out old books but was often keen on buying new books. He later realized that many of these old books were completely ruined and consequently appointed a specialist binder to look after the books in the library. Al-Jundī, Aḥmad Zakī, 115 .

100 Throughout the years of 1913-1920 he was accused of having doctored fake travel and gratuity reimbursements. His then 41-year-old financial secretary, Muhammad Effendi Khāțir, was proven guilty of putting his signature on these forms instead of Zakī Pasha and many other high officials in the cabinet for getting the money for himself. On 13 December 1921, Khāțir was convicted to five-years in prison. Egyptian National Archives, Papers Zakī Pasha, 5016-0oo425, file 6; 1 May 1923-26 February 1927. In late 1922 and early 1923, the founder of the Egyptian newspaper Al-Kashkūl, Sulaymān Fawzī, launched a sustained and sarcastic campaign against Zakī Pasha. He asserted that it was Zakī Pasha who forced his secretary to sign documents for several years. His resignation from his cabinet post was only an escape route, suggested to him by the Prime Minister 'Adlī Pasha in order to save his name. The founder of $A l-K a s h k u ̄ l$ was convicted of slander against Ahmad Zakī Pasha. Al-Kashkūl, 85, 31 December 1922, 86, 7 January 1923; 100, 15 April 1923. Papers Zakī Pasha, Egyptian National Archives, 5016-0oo425, file 6; 1 May 1923-26 February 1927. 
You should understand that with or without my official job I remain Ahmad Zakī Pasha. My service for my language, its literatures, sciences and knowledge is evident to everyone in the east and west [...]. I am proud of my work, which is the abiding 'crown' on my head. ${ }^{101}$

As a result, in August 1921 Zakī Pasha decided to endow his library to the Ministry of Awqāf (Religious Endowments) on the condition that it should remain under his supervision during his life. He preferred not to endow his library to the Ministry of Education as he feared that Douglas Dunlop, the Scottish missionary and British consultant to the Egyptian Ministry of Education, would put it under the control of another official bureau after Zakī Pasha's death. In his testament, Zakī Pasha stipulated that the library should be relocated to the building of the School of Al-Ashraf Qansuh al-Ghawrī, and should remain independent. After a few years, Zakī Pasha began to complain about the Ministry's negligence of his library. ${ }^{102}$ In December 1925, heavy rain was about to destroy the library, but it was rescued because of its guard's careful attention. In such moments, Zakī Pasha would ironically attack his library as "a multiplying burden". ${ }^{103}$ In December 1935, the Minister of Awqā ordered the library to be relocated again to the National Library where it is still kept today. ${ }^{104}$

\section{Printing, Translation and Arabization}

In addition to the field of manuscript editing, Zakī Pasha also contributed to the fields of printing, translation and Arabization. During his stay in Europe, he regularly visited European printing houses to observe new techniques of typesetting. At this time, the Egyptian government appointed a committee to study how to improve Arabic typography. This committee consisted of Zakī Pasha, Sheikh Ḥamza Fatḥallah, a literary and religious scholar, Amīn Sāmī Bey, Director of al-Nāșiriyya School, and Alfred Chelu Bey, Director of Bulaq National Printing Press. Together with Chelu Bey, Zakī Pasha travelled to Istanbul, Vienna, Oxford, Berlin and Leipzig in order to explore new applications of printing typeface on the Arabic script. They visited the wellknown Austrian publisher Adolf Holzhausen (1868-1931) and George Fritz, director-deputy of the Viennese Imperial and Royal Court and State Printing

\footnotetext{
101 Al-Jundī, Ahmad Zakī, 231.

102 Al-Jundī, Aḥmad Zakī, 116-117.

103 Al-Jundī, Aḥmad Zakī, 116-117.

104 Al-Jundī, Aḥmad Zakī, 118.
} 
House, to learn directly from the publisher about their printing of Arabic books. ${ }^{105}$ After months of testing in the Bulaq Printing House, the committee managed to reduce the Arabic type from 905 to 132 . Zaki Pasha believed that such a new technique would reduce the cost of printing by $25 \%$ as compared to the existing system. ${ }^{106}$

Moreover, Zakī Pasha introduced a punctuation system for the Arabic script that resembled European punctuation signs. He argued that this systemic punctuation in European publications enables young learners of European languages to read long texts continuously and accurately without many pitfalls. On the other hand, Arabic-speaking students were not able to accurately read Arabic texts due to the lack of punctuation. He also aimed at developing a shorthand system for Arabic by announcing a competition and a prize of fifty Egyptian pounds for anyone excelling in Arabic shorthand, but nobody was found. ${ }^{107}$

In regard to the field of translation, the Egyptian government funded several translation projects of European works. Zakī Pasha translated a few French works into Arabic, such as Frédéric Bonola Bey's L'Egypte et la géographie, which was originally a lecture given by the author at the Egyptian Geographical Society in French in $1890 .{ }^{108}$ His Arabic translation of Gaston Maspero's Histoire de l'Orient into Arabic (1897) was financed by the Ministry of Education, and became a standard text in the curricula of secondary public schools in the late nineteenth and early twentieth century. ${ }^{109} \mathrm{He}$ also translated a few French short novels in the Egyptian press, such as Victor Hugo's Le Dernier Jour d'un Condamné. ${ }^{110}$

In his official post in the Council of Ministers, Zakì Pasha made use of his philological expertise to Arabize existing European and Ottoman bureaucratic, legal and political terms, and managed to replace them with their equivalents after meticulous research in classical compendia of fatwas, lexicography

105 Verhandlungen XIII. Internationalen Orientalisten-Kongresses, Hamburg September 1902, Leiden: Brill, 1904, 289 .

106 Al-Jundī, Aḥmad Zakī, 68, citing al-Muqtataf, April 1903.

107 Al-Jundī, Aḥmad Zakī, 73 .

108 Frédéric Bonola Bey, L'Egypte et la géographie sommaire historique des travaux géographiques exécutés en Egypte sous la dynastie de Mohammed Aly, Société khédiviale de geéographie La Caire, Imprimerie Nationale, 189o. Kitāb Mișr wa al-Jughrāiya, translated by Aḥmad Zakī Pasha, Cairo: Al-Mațba'a al-Amīriyya, 1892.

109 Tārikh al-Mashriq, First edition, Cairo: al-Mațba al-Amīriyya, 1897. Hindawi Foundation for Education and Culture, 2014. Available at http://www.hindawi.org/books/48302735/ (Accessed on 20 April 2017).

110 Al-Jundī, Aḥmad Zakī, 44. 
and literature. In that sense, he tended to insert simple but elegant Arabic terms as a way of reforming the Arabic language in the bureaucratic system. He did not like the methods of some Arab philologists in using difficult and archaic phrases from what he calls qa' ral-qāmūs, or the abyss of dictionaries. ${ }^{111}$ Regarding Egyptian colloquial Arabic, there are many non-Arabic words borrowed either from ancient Egyptian languages, Persian, Ottoman or French. Zakī Pasha made several attempts to examine some of these words by tracing them to their supposed original languages, which as usual provoked interesting philological debates in the Arabic press. One such humorous philological exercise in the Egyptian daily Al-Ahräm was his explanation of the Egyptian colloquial phrase "ala al-hurkruk" (at the last moment) which he attributed to the French ric-a-ric (meaning 'exactly'). During the period of French occupation, he argued, Egyptians took the phrase from French soldiers on the street but added the $h a$ to it. Other philologists did not agree with his interpretation. ${ }^{12}$

It is also interesting to note that Zakì Pasha was the first to have given the name "darräja" to "bicycle". He was also the first Egyptian high civil functionary to ride a bicyle in public in Cairo. ${ }^{113} \mathrm{He}$ also initiated the word "sahăfi" for "journalist" and "sayyāra" for "automobile." Sayyāra was immediately inserted as the standard word in transport departments in the government. ${ }^{114}$ Zakì Pasha made use of his knowledge to find the meaning of obscure Arabic vocabulary of which the origin is sometimes lost. If he failed, he would immediately seek help by raising the issue in the press. ${ }^{115}$ In addition, he urged Arab writers "to shoulder up in order to elevate the status of Arabic in the direction of modern progress, in order that it should fulfil our needs in communication and elucidation." 116

\footnotetext{
111 Al-Jundī, Aḥmad Zakī, 177.

112 See Yunān Labib Rizq, "Min Gharā’ib mufradāt al-āmiyya al-mișriyya”, Diwān al-Ḥayāh al-Mu'āṣira, Al-Ahrām, 4 July, 2002; http://www.Ahrām.org.eg/Archive/2002/7/4/FILE1 .HTM (Accessed on 27 March 2017).

113 Al-Jundī, Ahmmad Zakī, 271.

114 Al-Jundī, Ahmmad Zakī, 75 .

115 For example, in 1929, C.V. Ode-Vassilieva, a minor Russian Muscovian Orientalist of Arab origin and author of the glossary Modern Arabic Chrestomathy (1929), sent him a letter asking about the origin of word jura, referring to a seat used by women during the delivery of birth. Ode-Vassilieva, also a student of the well-known Palestinian Christian literary figure and Arabist Khalīl al-Sakākīnī (1878-1953), came across the term during her field work, but failed to find its origin. As Zakī Pasha failed too, he raised the question in the press. See, Al-Hilāl, 37/7, 1 May 1929, 857-859.

116 Al-Jundī, Aḥmad Zakī, 75 .
} 


\section{Intellectual Debates}

Zakī Pasha preferred writing in the press to authoring books. In his debates with his Arab intellectual peers, he boastfully declared his views as always better than those of his counterparts. His controversial claims intensified after his resignation in 1921, which gave him a wide fame in the Arab world regarding various literary, historical, religious and linguistic issues. He often preluded his debates by the statement: "'annī wa 'annī waḥd̄̄ khudhū al-khabar al-șādiq (Take the truth on my authority, and my authority only)". ${ }^{117}$ Another favorite phrase of his was "wa li kullu yawm mawqif wa maqālah (Every day, I have a [different] position and a [different] article)."118

His answers to his rivals in the press were full of humor, irony, temper, and harsh phrases. His most famous literary and linguistic debates were against such famous writers as his former student Ṭāha Ḥusayn, 'Abbās Mạ̣mūd al'Aqqād, Zakī Mubārak and the Egyptian writer Muḥammad Mas'ūd. ${ }^{119}$ His longest debate was against Mas'ūd which centered on the Muslim history of Spain and the supposed Arab arrival in the Americas. ${ }^{120}$ He even sometimes belittled his opposing debaters as "childish," "confused" and "ignorant". ${ }^{121}$

In 1916, in a public lecture, Zakī Pasha ridiculed 'Alī Bahjat (1858-1924), secretary general of the Committee of the Conservation of the Monuments of Arab Arts, for the latter's ascribing of an antique cup to the Muslim warrior Saladin. ${ }^{122}$ Another stern debate was his vehement rejection of the authenticity of the papyri of the letters ascribed to the Prophet, which the Prophet had sent to contemporary leaders. A certain Ahmad Mannā' 'Arafa, a legal expert in Alexandria, asserted that he sent Sultan Abdulhamid a precious present, which was a box containing an old copy of the Qur'ān and the Prophet's message to Najāshī, the King of Abyssinia. 'Arafa inherited the box from his noble ancestors in the city. Zakī Pasha deemed such claims as historical forgery, which some

\footnotetext{
117 Al-Jundī, Ahmad Zakī, 39.

118 Al-Jundī, Aḥmad Zakī, 7 .

119 Muhammad Mas'ūd, al-Minḥ̣a al-Dahriyya fí Takhțịt Madīnat al-Iskandariyya, Alexandria, 1308/[1890-1891].

120 al-Jundī, Ahmad Zakī, 210-218.

121 Al-Jundī, Ahmad Zakī, 190-194.

122 See his address to the Institut d'Égypte, Al-Ahrām, 4 April 1916; 9 May 1916; 11 May 1916; 13 May 1916. Ali Bahjat is the author of Qāmūs al-amkina wa-al-biqà allatī yarid dhikruhā fì kutub al-futūh (The glossary of locations and places which are mentioned in the Books of Islamic Conquests), Cairo, 1907.
} 
orientalists had already debunked in their research, such as François Alphonse Belin (1817-1877). ${ }^{123}$

The debates were also extended to Coptic writers. In 1931, a fierce debate erupted between Zakī Pasha and Morcus Semeika Pasha (1864-1944), the founder and first director of the Coptic Museum in Cairo, when the latter published a chapter on "Churches in Egypt" in the official almanac of the Egyptian Ministry of Finance. Semeika Pasha asserted that the Fatimid Caliph al-Mu'izz Li-dīn Allāh al-Fāțimī (932-975) had converted to Christianity and was secretly baptized in the Coptic church of Abū Sayfin in Old Cairo. This assertion caused a huge controversy among Egyptian writers and historians that year. ${ }^{124}$ An anonymous journalist published Zakī Pasha's response in a treatise along with the views by other Muslim writers against Semeika Pasha, so as to "unravel" the "plot" of Morcus against Muslims. ${ }^{125}$ Zakī Pasha was startled that such a "gruesome" falsification was established by a respected scholar and colleague in the committee of Arabic archaeology. For Zakì Pasha, such an old Coptic legend was not supported by any "Western or Eastern" historical source. For him, Semieka Pasha followed Christian clergymen who preached such "lies" among the followers of the Church. ${ }^{126}$ In his answer, Semeika disagreed and cited Alfred Butler (1850-1936) that "the Sultan was baptized on his conversion to Christianity."127 Semieka Pasha requested Zakī Pasha to visit the Church in order to witness the place of the assumed baptizing, and to know that this account had been reported in the Church for hundreds of years. Muslim writers considered Semeika Pasha's assertion as a "hidden" Christian missionary scheme to confuse Muslims regarding the founder of al-Azhar Mosque. After a press campaign and a special meeting with the Prime Minister Șidqi Pasha (1875-1950), Semeika Pasha finally clarified that he mentioned the story in the almanac merely as part of the history of the Church, without believing it himself. The same holds true to the history of many archeological sites in the world which are often associated with legendary narratives. ${ }^{128}$

At another level, Zakī Pasha did not take some of the early Islamic historical narratives for granted. For example, he did not accept the story of the splitting

123 Al-Jundī, Aḥmad Zakī, 198-200.

124 Anonymous writer H, Al-Khalîfa al-Mu'izz li-Dìn Allah, Bānī al-Qāhira wa munshi' al-Jāmic al-Azhar ma kāna murtaddan wa lā nașrāniyya wa lākin kāna hanīfan musliman, Cairo: n.p., 1931.

125 H., al-Khalïfa al-Mu izz, 25-28. See also Al-Ahräm, 7 August 1931 and 19 August 1931.

126 H., al-Khalïfa al-Mu'izz, 25-28. See also Al-Ahräm, 7 August 1931 and 19 August 1931.

127 Alfred Butler, The Ancient Coptic Churches of Egypt, Oxford: Clarendon Press, 1884, 117.

128 H., Al-Khalifa al-Mu'izz, 62. See also Al-Ahrām, 20 August 1931. 
of the moon on the day of the Prophet's death. The Qur'annic reference to the splitting of the moon is only related to the Day of Resurrection, and it never happened as a miracle in the Prophet's lifetime. For him, such a story was forged by the Jewish convert to Islam, Kab al-Ahbār, and incorporated into Islamic history in order to mislead common Muslims, who were trapped into believing it as a miraculous sign. Unfortunately, Muslim exegetes followed them without taking into consideration the negative consequence of such stories. ${ }^{129}$ Another early Muslim narrative was the account of the Kingdom of Solomon as having extended over the whole world. Zakī Pasha requested al-Azhar scholars as "protectors of religion" to openly reject such views. ${ }^{130}$ In his view, the Kingdom of Solomon did not expand further than the region of Bilād al-Shām (Greater Syria), and any other accounts were nothing by myth. Moreover, the "valley of ants" mentioned in the Qur'ān did not refer to real ants, but to large groups of farmers and workers who fled to their homes after they had encountered the army of Solomon on the roads to Jerusalem. The Qurān metaphorically portrayed them as mere "ants" by their number and cowardliness. ${ }^{131}$ Al-Ṣādiq 'Arjūn (1903-1981), then a graduate of al-Azhar and later dean of the Faculty of Theology, attacked Zakī Pasha, saying that his standing as Shaykh Al-'Urūba did not give him the right to involve himself in Qur'ānic exegesis. ${ }^{132}$

Zakī Pasha exploited historical discoveries against popular religious beliefs in Egypt. For example, he rejected the idea that the shrine of Zaynab (d. 681), the daughter of 'Alī Ibn Abī Taalib, in Cairo contains the remains of her body, since she had never travelled to Egypt. The shrine only existed a few years before the era of Muhammad 'Alī Pasha. In the debate, it was argued that the shrine was built by the Mamluk Sultan of Egypt Kitbugha (d. 1297) after some religious men had convinced him to build a mosque at this site where a holy woman named Zaynab had been buried. The masses later believed that it was Zaynab, the daughter of 'Alī. ${ }^{133}$ The same holds true for claim that the head of Husayn, the grandson of the Prophet, is buried in the shrine in Cairo. ${ }^{134}$

\footnotetext{
129 Al-Ahrām, 21 August 1929. See responses to his views, 30 August 1929.

130 Al-Jundī, Aḥmad Zakī, 207-208.

131 Al-Ahrām, 5 \& 6 August, 1933.

132 Al-Jundī, Aḥmad Zakī, 208-209.

133 Al-Jundī, Ahmad Zakī, 146-147.

134 Al-Jundī, Aḥmad Zakī, 148.
} 


\section{Political Action}

Zakī Pasha's life was not entirely detached from politics. He was a loyalist to the Khedival Palace and did not divulge any open anti-Royal or anti-British views in public. ${ }^{135}$ Due to his close relationship with Khedive 'Abbās he chose not to take part in any revolutionary nationalist course of action, which may explain Zaghlūl's dismissive remark about him. As Secretary of the Egyptian University, he tried to suppress any emerging political nationalist movements and parties at the new institution. On their part, Egyptian nationalist groups attacked Zakī Pasha for his campaign against them. In Alexandria (11 Sept. 1908), he addressed the first Egyptian student mission of the university to Europe by urging them to restore Egyptian "glory" by means of disciplined work, but not by "shouting" and "screaming" abroad. ${ }^{136}$ After a press campaign by the National Party, Zakī Pasha resigned from his lecturing position at the university. ${ }^{137}$ Due to his good relations with Khedive 'Abbās and Sultan Hussein of Egypt after him, Zakī Pasha was not on good terms with their successor King Fu'âd, especially after the latter's accession to the throne in 1917. Immediately in May 1921, after the abovementioned corruption accusation and his acquittal, Zakī Pasha finally resigned, ${ }^{138}$ and started a new chapter of his career in Arab politics. It is in this period of his career that Zakī Pasha began to call himself Sheikh al-'Urūba (Dean of Arabism) and his residence in Giza as Dar al-'Urūba (House of Arabism), which he often used under his signature of press articles. His pan-Arab political action was crystalized in his mediation in the YemeniSaudi conflict and the question of Palestine in the late 1920s.

Besides his active participation in freemasonry, he turned to the idea of pan-Arabism and the unity of Oriental nations by co-founding al-Rābița alSharqiyya (1922, The Association of Oriental Bond), which included Arabs, Turks, Indians, Indonesians and Persians. ${ }^{139}$ One of the most important aims of the association was "to strengthen the bonds among Eastern people, with intellectual cooperation, study of Eastern civilization, and to borrow what

\footnotetext{
135 Al-Jundī, Aḥmad Zakī, 232.

136 Al-Jundī, Ahmad Zakī, 227-228.

137 Al-Jundī, Ahmad Zakī, 78.

138 Al-Jundī, Ahmmad Zakī, 228-229.

139 See, for example, Al-Manār, vol. 23/3, (March 1922), 219-222. Cf. James Jankowski, "The Eastern Idea and the Eastern Union in Interwar Egypt," The International Journal of African Historical Studies, 14/4 (1981), 643-666.
} 
is appropriate from Western civilization." ${ }^{140}$ Zakī Pasha in particular was of the view that the key to Eastern unity was the promotion of the triangle of Arab, Turkish and Persian cultures. Each of these civilizations should take its separate course of progress without losing its strong bond with the other two. By uniting the three civilizations and their peoples, a strong coalition in the face of the colonial powers could be established. ${ }^{141}$

In July 1926, he travelled to Yemen and the Hijaz in the company of his friend Nabīh al-Azmeh (1886-1972), a Syrian nationalist, in order to mediate between Imam Yahya and Ibn Sa ūd in their border conflicts. During this visit, he studied the epigraphy in the Himyari language, and collected manuscripts and antique statues and swords. Zakì Pasha remained silent about the political aspects of his visit, but in al-Hiläl magazine he only gave an impression of his stay and impressions of Yemen. Zakī Pasha started his mission in Yemen, as he believed that relations had to be first established on the side of the Zaydi Yemeni leaders above their Wahhābi Saudi counterparts, and because of the killing of around 3000 Yemeni pilgrims by the Saudi troops in $1921 .{ }^{142}$

Zakī Pasha's experience in Yemen was very harsh. He suffered a lot of discomfort as a result of the uncomfortable road and transport from Aden to Mocha and finally to Sanaa. ${ }^{143}$ His observations of the country and its culture were generally negative, especially in relation to what he considered as the primitive economic, agricultural and industrial situation. He bemoaned the lower status of women and how women covered their bodies. If children joined schools, they were educated in an old-fashioned way, placing a wooden dagger on a boy's waist in order for them to be brought up knowing how to defend their rights. Zakī Pasha even noted that Abyssinian and Sudanese slaves still existed in Yemen. ${ }^{144}$ In Yemen, however, Zakī Pasha embraced the title of Sheikh al-'Urūba. In Sanaa, he had himself photographed in Bedouin

\footnotetext{
140 Noor-Aiman I. Khan, Egyptian-Indian Nationalist Collaboration and the British Empire, Springer, 2011, 101-102.

141 Al-Jundī, Ahmmad Zakī, 236.

142 Al-Hiläl, vol. 37/9, 1 July 1929, 1046. They brought with them lots of presents to the Imam as they were obliged to stay in his royal court for the lack of hotels in Sanaa, except what they called "samsarah", a name for lodging places and pensions. About Saudi-Yemeni relations, see Laura Etheredge, Saudi Arabia and Yemen, The Rosen Publishing Group, 2011.

143 Al-Hiläl, vol. 37/9, 1 July 1929, 1048. In the court of Imam Yahya, they were warmly welcomed. When the Imam greeted him in Arabic "ahlan wa sahlan wa marhaban (i.e. welcome; but literally means welcome to our wide valley). He ironically told the Imam that he should welcome his guests by saying "ahlan wa jabalan marhaban (welcome to our wide mountain)", as the country has nothing but mountains.

144 Al-Hiläl, vol. 37/9, 1 July 1929, 1048.
} 
attire. Having seen the photograph, Sayf al-Islam Ali, son of Imam Yahya, commented: "this is Shaykh al-'Arab." From this time on, Zakī Pasha, who was no modest man, signed his works as the Sheikh of Arabism. ${ }^{145}$

In the wake of the Buraq Uprising 1929 (also known as the 1929 massacres), Zakī Pasha was dispatched by al-Rābița al-Sharqiyya to defend the Muslim side in the Western Wall Commission. It is important to note that a few years earlier, Zakī Pasha was accused in the Palestinian newspaper, Filasțin, of having sent a letter to a certain Dr. David Idar, a fellow freemason and head of the Executive Zionist Committee, to congratulate him on the establishment of a Zionist state in the region. Zakī Pasha immediately sent a telegram to the Arab Club in Jerusalem to clarify the contents of his letter. ${ }^{146}$

During his stay, Zakī Pasha received letters from Muslims in various regions supporting him as a representative to the committee, including the Mufti of Poland Jakub Szynkiewicz (1884-1966). ${ }^{147}$ He verbally elaborated Arab contentions to a historical report prepared by David Yellin (1864-1941), a Jewish educator and an expert in Arabic literature. ${ }^{148}$ In his preparation of the report, Zakī Pasha commissioned the Jewish scholar Israel Wolfonson, a student of the Egyptian intellectual Țaha Hussayn, to collect modern Western historical sources on Jerusalem. ${ }^{149}$ For the committee, Zaki Pasha made more than a hundred photos of locations and Islamic inscriptions on the wall and the Aqsa Mosque, which are still preserved in his collection in the National Archives of Egypt. ${ }^{150}$

In his speech in French before the commission, Zaki Pasha stressed that Muslims "state that all contentions relative to Moslem sacred places should be dealt with only by competent bodies as prescribed by the Sharia Law. Other bodies can have no jurisdiction whatever by the Sharia Law. Other bodies can have no jurisdiction whatever on these places." ${ }^{151} \mathrm{He}$ explained to the

\footnotetext{
145 Al-Jundī, Ahmad Zakī, 244-245.

146 Filasțin, 20 October 1922. See also the defense of Sheikh 'Ali Surūr al-Zankalūnī, "Aḥmad Zakī Pasha wa al-șuhyūniyya", Al-Ahrām, 27 October 1922; Cf. Al-Ahrām, 28 Oct. 1922.

147 See his letter to Zakī Pasha, 8 July 1930. See also Aḥmad Zakī's articles about Palestine in Al-Ahrām, 17 November 1929; 8 April 1930; 16 June, 1930; 28 July, 1930; 3 August 1930.

148 Hillel Cohen, Year Zero of the Arab-Israeli Conflict 1929, trans by Haim Watzman, Brandeis University Press, 2015, 62.

149 He provided Zakī Pasha with such works as John Kelman, The Holy Land, Adam and Charles Black, ıst edition, 1902. See letter, no date, 37, Papers Ahmad Zakī, National Archives of Egypt, 5016-000449.

150 See Papers Ahmad Zakī, National Archives of Egypt, 5016-000422.

151 See Report of the Commission appointed by His Majesty's Government in the United Kingdom of Great Britain and Northern Ireland, with the approval of the Council of
} 
commission that Palestine "was not a Jewish kingdom that the Arabs occupied in the 7th century, but a country to which the Jews had no right whatsoever." Since the Conquest of 'Umar to the city of Jerusalem in the early Islamic era, the country had been in the hands of the Arabs from generation to generation with the exception of go years during the Crusades. He went on, the Jews who later came to Palestine were not interfered with by the Arabs who treated them well. During the centuries of Muslim rule, there were neither incidents at the Buraq, nor did the Jews claim any rights to the Wall. They were assured that the "tolerant" Arabs would not interfere with them. Zaki Pasha stressed that the Balfour Declaration and the terms of the League of Nations Mandate were the cause of this issue being raised, which finally brought bloodshed in Palestine and had incited the Jews to press such claims. He argued that the creation of a Jewish national home in an Arab country would only give rise to perpetual troubles and dissensions. Regarding the Jewish rights to the Wall, Zakì Pasha contended that its property belonged to the Muslims for many centuries, and not a single stone of the Wall dated back to the days of Solomon..$^{152}$

\section{Conclusion}

Zakī Pasha was a complex character who combined his position as a government bureaucrat with many literary and intellectual activities in colonized Egypt. This article has demonstrated that he possessed political power, rich scholarly networks, and multiple intellectual resources and talents. Ronen's metaphor of the Arab-Orientalist encounter as a "transparent mirror" is true when we look at Zakī Pasha's Western and Eastern scholarly networks. He proudly perceived himself as a unique "oriental" scholar who successfully joined "orientalist" circles. His attendance at the Congress of Orientalists in London at a young age must have consolidated this feeling, which was reflected in his attitudes to his scholarly life. His writings, encounters and correspondences with European orientalists show a degree of mutual respect. However, he is rather remembered as a high Egyptian bureaucrat who exceptionally combined his governmental post with literary talents as a prolific writer and historian. His

the League of Nations, to determine the rights and claims of Moslems and Jews in connection with the Western or Wailing Wall at Jerusalem, London, 1930, 19. It contains a full summary of his speech before the commission. http://repository.un.org/bitstream/ handle/11176/76166/S_8427_Add.1-EN.pdf?sequence=1\&isAllowed=y (accessed on 20 October 2017).

152 See, Report of the Commission. 
life developed into a fascinating engagement with Europe and knowledge about Arab culture in modern history. Various overlapping but distinctive themes of interest are evident throughout his career in the realms of thought, culture, literature, and politics. The most prominent of these were his cultural and social encounters in Europe and academic engagements with European intellectuals, his contributions to the discourse of language and cultural revival and pan-Arabism. His exchanges with Orientalists in particular were part of a broader growing dialogue that emerged in the late nineteenth century between orientalists and Arab intellectuals.

Zaki Pasha regularly underlined the significance of Arab civilization to contemporary society. He took comfort in borrowing from European ideas in order to reclaim Arabic and Islamic heritage. He also had no trouble in integrating Western ideals with religious ideals in his discourse. Positioning himself at the forefront of Arabic scholarship of his age, he became concerned with finding suitable media that would sustain this scholarship and its narratives of belonging, which was already tarnished in the colonial age.

Zaki Pasha's interest in the revival of the Arab past was spurred by urgent challenges facing the Arabs under colonialism. His attempts at reforming the Arab printing and letters and editing of Arabic classics should be seen as part of a wider context of pan-Arab hopes that emerged among many of his intellectual peers in the Arab world. His practical achievements in Arabic studies and extensive writings in the press on culture, politics, history and language captured the attention of many among Arab political circles, which allowed him to play the role of moderator in the negotiations of the YemeniSaudi conflict and the Palestinian cause.

\section{Archive}

Papers Aḥmad Zakī, National Archives of Egypt, 5016-0o0422. Papers Zakī Pasha, National Archives of Egypt, 5016-000424. Papers Zakī Pasha, National Archives of Egypt, 5016-000426. Papers Aḥmad Zakī, National Archives of Egypt, 5016-ooo449.

\section{Periodicals}

Al-Ahrām, 28 Oct. 1922.

Al-Ahrām, 17 November 1929.

Al-Ahrām, 8 April 1930. 
Al-Ahrām, 16 June 1930.

Al-Ahrām, 28 July 1930.

Al-Ahrām, 3 August 1930.

Al-Hiläl, vol. 35/5, 1 March 1927.

Al-Hilāl, vol. 37/7, 1 May 1929.

Al-Hiläl, vol. 37/9, 1 July 1929.

Al-Manār, vol. 23/3, March 1922, 219-222.

'Alī, Kurd, "Al-Khizana al-Zakīyya," al-Muqtabas, 79, 1 Sept 1912.

Rizq, Yunān Labib. "Min Gharāib mufradāt al-āmiyya al-mișriyya”, Diwān al-Ḥayāh al-Mu'āṣira, Al-Ahrām, 4 July, 2002; http://www.Ahrām.org.eg/Archive/2002/7/4/ FILE1.HTM (last access 27 March 2017).

Zankalūnī, Sheikh 'Ali Surūr al-. "Aḥmad Zakī Pasha wa al-Suhyuniyya". Al-Ahrām, 27 October 1922.

\section{Other Printed Sources}

Amherst, Alicia M.T. The History of Gardening in England. Barsinghausen: UnikumVerlag, 1896.

Annymous writer H. Al-Khalīfa al-Mu'izz li-Dìn Allah, Bānì al-Qāhira wa munshì al-Jāmi al-Azhar ma kāna murtaddan wa lā nașrāniyya wa lākin kāna hanüfan musliman. Cairo, 1931.

Arberry, John. "A Fresh Light on Ahmad Faris al-Shidiaq." Islamic Culture, 26/1 (Jan. 1952), 155-168.

Aydin, Cemil. The Idea of the Muslim World: A Global Intellectual History. Cambridge, Massachusetts: Harvard University Press, 2017.

Bahjat, 'Alī. Qāmūs al-amkina wa-al-biqà allatī yarid dhikruhā fì kutub al-futūh. Cairo, 1907.

Bakrī Muḥammad Tawfīq al-. (1870-1932), Sahārīj al-Iu’lu’. Cairo: Mațba'at aI-Hilāl, 1906.

Batanūnī, Muḥammad Labīb al-. Riḥlat al-Ṣayf ilā Urūbbā. Cairo: Maṭba'at al-Liwā', 1901.

Bik, Rashād. Siyāḥa fì al-Rūsiyya. Hindawi Foundation for Education and Culture, 2012; available at http://www.hindawi.org/books/40206035/ (last view 20 October 2017).

Bonola Bey, Frédéric. Kitāb Miṣr wa al-Jughrāfiya, translated by Aḥmad Zakī Pasha. Cairo: Al-Matba'a al-Amīriyya, 1892.

Bonola Bey, Frédéric. L'Egypte et la géographie sommaire historique des travaux géographiques exécutés en Egypte sous la dynastie de Mohammed Aly. Société khédiviale de geéographie La Caire, Imprimerie Nationale, 1890.

Butler, Alfred. The Ancient Coptic Churches of Egypt. Oxford: Clarendon Press, 1884. 
Cohen, Hillel. Year Zero of the Arab-Israeli Conflict 1929, trans. by Haim Watzman. Brandeis University Press, 2015.

Dabbus, Fahd Nayif al-, al-Raḥhāla al-Arab wa Intiba'atuhum 'an al-ma'ārị̣ al-dawliyyaI 1851-19oo, Kuwait: Dabus Center, 2009.

Douglas, Robert K. (ed.). Transactions of the Second Session of the International Congress of Orientalists. London: Trübner \& Co., 1876.

Etheredge, Laura. Saudi Arabia and Yemen. The Rosen Publishing Group, 2011.

Geaves, Ron. Islam in Victorian Britain: The Life and Times of Abdullah Quilliam. Markfield: Kube Publishing Ltd, 2010.

Goldschmidt, Arthur (ed.). Biographical dictionary of modern Egypt. Lynne Rienner Publishers, 2000.

Grenfell, Bernard P. \& Arthur S. Hunt. The Amherst Papyri: being an account of the Greek papyri in the collection of Lord Amherst of Hackney, Didlington Hall, Norfolk. London: s.n., 1900-1901.

Het Leidsche Orientalistencongres. Leiden: Brill, 1883.

Heyworth-Dunne, J. "Printing and Translation under Muhammad Ali of Egypt.” Journal of the Royal Asiatic Society, 2/3 (June 1940), 325-349.

Ḥusayn, Țāha. Al-Ayyām. Cairo: Al-Ahrām Centre for Publication and Translation, 1992.

Jankowski, James. "The Eastern Idea and the Eastern Union in Interwar Egypt". The International Journal of African Historical Studies, 14/4 (1981), 643-666.

Jundī, Anwar al-. A ḥmad Zakī al-mulaqqab bi Shaykh al-Urūba. Cairo: Ministry of Culture and National Guidance, 1963, 121.

Jung, Dietrich. Orientalists, Islamists and the Global Public Sphere: A Genealogy of the Modern Essentialist Image of Islam. Equinox Publishing, 2011, 115.

Kelman, John. The Holy Land. Adam and Charles Black, 1st edition, 1902.

Khallāț, Nasīm. Siyāha fi al-gharb al-Urūbbì. Cairo: Mațba'at al-Muqtațaf, 1901.

Khan, Noor-Aiman I. Egyptian-Indian Nationalist Collaboration and the British Empire. Springer, 2011.

Khūja, Muḥammad Ibn al-. Sulūk al-ibrīz fi masālik Barìz. Tunis: al-Maṭba‘a al-Rasmiyya, 1900.

Little, Donald P., ed. Essays on Islamic Civilization. Leiden: Brill, 1976.

Longeard, Gwladys. "L'Imprimerie nationale pendant la Commune de 1871". In Revue d'histoire moderne et contemporaine 1/2005 (No 52-1), 147-174.

Mas'ūd, Muḥammad, al-Minḥa al-dahriyya fi takhțīt Madinat al-Iskandariyya. Alexandria, 1308/[1890-1891].

Morgan, E. Delmar, ed. Transactions of the Ninth International Congress of Orientalists held in London, 5th to 12 September 1892. London: Committee of the Congress, 1893

Muhanna, Elias Ibrahim. The World in a Book: Al-Nuwayri and the Islamic Encyclopedic Tradition. Princeton University Press, 2018. 
Muwayliḥi, Muḥammad al-. Hadīth Isa b. Hishām aw fatra min al-zamān. 4th ed., Cairo: Maṭba'at Misr, 1927.

Newman, Daniel. "Myths and realities in Muslim Alterist discourse: Arab travellers in Europe in the age of the Nahda (19th c.)". Chronos, 6 (2002), 7-76.

Noorani, Yaseen. "The Lost Garden of al-Andalus: Islamic Spain and the Poetic Inversion of Colonialism". International Journal of Middle East Studies, 31/ 2 (May, 1999), 237-254.

Nuwayrī, Shihāb al-Dīn Aḥmad b. 'Abd al-Wahhāb al-. Nihāyat al-arabfífunūn al-adab, eds. Aḥmad Zakī Pāsha et al. Cairo: al-Mu’assasa al-Miṣriyya al-'Āmma li-'l-Ta'lîf wa-'l-Tarjama wa- 'l-Ṭibā'a wa-'l-Nashr, 1923-97.

Pinches, Theophilus G. The Amherst tablets: being an account of the Babylonian inscriptions in the collection of the Right Hon. Lord Amherst of Hackney, F.S.A. at Didlington Hall, Norfolk. London: Quaritch, 1908.

Ramaḍān, 'Abd al-'Az̄īm, ed. Mudhakkirāt Sa'd Zaghlūl. Cairo: Al-Hay’a al-Mișriyya al'Āmma li al-Kitāb, 1988.

Raz, Ronen. "The Transparent Mirror: Arab Intellectuals and Orientalism, 1798-1950." PhD Thesis, Princeton University, 1997, 24.

Reid, Donald Malcolm. Cairo University and the Making of Modern Egypt. Cambridge University Press, 2002.

Report of the Commission appointed by His Majesty's Government in the United Kingdom of Great Britain and Northern Ireland, with the approval of the Council of the League of Nations, to determine the rights and claims of Moslems and Jews in connection with the Western or Wailing Wall at Jerusalem, London, 1930, 19. It contains a full summary of his speech before the commission: http://repository.un.org/bitstream/ handle/11176/76166/S_8427_Add.1-EN.pdf?sequence $=1$ \&isAllowed $=y$ (last access 20 October 2017).

Ryad, Umar. Islamic reformism and Christianity. Leiden: Brill, 2009.

Tārikh al-Mashriq. First edition, Cairo: al-Mațb`a al-Amīriyya, 1897.

Thompson, Jason. “Edward William Lane's 'Description of Egypt”. International Journal of Middle Eastern Studies, 8/iv (Nov. 1996), 565-583.

Travaux de la troisieme session du congres international des orientalistes. St. Petersburg, 1879-188o.

'Umarī, Ibn Fạ̣l Allah al-. Masālik al-abṣar fi mamālik al-amṣar, ed. Aḥmad Zakī Pasha. Cairo, 1924.

Verhandlungen XIII. Internationalen Orientalisten-Kongresses, Hamburg Sepetmber 1902. Leiden: Brill, 1904.

Way, Twigs. Virgins, Weeders and Queens: A History of Women in the Garden. Stroud: The History Press, 2006.

Zakī, Aḥmad. al-Safar ilā al-Mu’tamar. Cairo: Bulāq, Second Edition, 1894, 7-8.

Ziriklī, Khayr al-Dīn Al-. Al-A'lām. Beirut: Dār Al-'Ilm lil-Malāyīn, 15th edition, 2002. 